\title{
Mutations in Plasmodium falciparum Dihydrofolate Reductase and Dihydropteroate Synthase of Isolates from the Amazon Region of Brazil
}

\author{
KF Vasconcelos, CV Plowe*, CJ Fontes**, D Kyle***, DF Wirth****, \\ LH Pereira da Silva*****, MG Zalis ${ }^{+}$
}

Laboratório de Biologia da Malária, Instituto de Biofísica Carlos Chagas Filho, UFRJ, Cidade Universitária, Ilha do Fundão, 21949-900 Rio de Janeiro, Brasil *Malaria Section, Center for Vaccine Development, University of Maryland School of Medicine, USA **Universidade Federal do Mato Grosso, Cuiabá, MT, Brasil ***Department of Experimental Therapeutics, WRAIR, USA ****Department of Immunology and Infectious Diseases, Harvard School of Public Health, USA *****Centro de Pesquisa em Medicina Tropical, Porto Velho, RO, Brasil

Since the late 1970s pyrimethamine-sulfadoxine (PS; Fansidar ${ }^{T M}$ Hoffman-LaRoche, Basel) has been used as first line therapy for uncomplicated malaria in the Amazon basin. Unfortunately, resistance has developed over the last ten years in many regions of the Amazon and PS is no longer recommended for use in Brazil. In vitro resistance to pyrimethamine and cycloguanil (the active metabolite of proguanil) is caused by specific point mutations in Plasmodium falciparum dihydrofolate reductase (DHFR), and in vitro resistance to sulfadoxine has been associated with mutations in dihydropteroate synthase (DHPS). In association with a proguanil-sulfamethoxazole clinical trial in Brazil, we performed a nested mutation-specific polymerase chain reaction to measure the prevalence of DHFR mutations at codons 50, 51, 59, 108 and 164 and DHPS mutations at codons 436, 437, 540, 581 and 613 at three sites in the Brazilian Amazon. Samples from two isolated towns showed a high degree of homogeneity, with the DHFR Arg-50/Ile-51/Asn-108 and DHPS Gly-437/Glu-540/Gly-581 mutant genotype accounting for all infections in Peixoto de Azevedo $(n=15)$ and $60 \%$ of infections in Apiacás $(n=10)$, State of Mato Grosso. The remaining infections in Apiacás differed from this predominant genotype only by the addition of the Bolivia repeat at codon 30 and the Leu-164 mutation in DHFR. By contrast, 17 samples from Porto Velho, capital city of the State of Rondônia, with much in- and out-migration, showed a wide variety of DHFR and DHPS genotypes.

Key words: Plasmodium falciparum - malaria - dihydrofolate reductase - dihydropteroate synthase drug resistance - Brazilian Amazon

Malaria is one of the major public health problems in Brazil, with 450,000 cases (about 77.2\% Plasmodium vivax and $21.8 \%$ P. falciparum) and approximately 10,000 deaths reported annually (Marques 1995). The Amazon region, in which migrant populations, great distances, and poor access to diagnosis and treatment are the major obstacles to malaria control, accounts for more than 95\% of the cases in Brazil (Marques 1993, 1995).

Compounding the existing problem is the emergence and spread of $P$. falciparum resistant to chloroquine and pyrimethamine-sulfadoxine (PS; Fansidar ${ }^{\mathrm{TM}}$ Hoffman-LaRoche, Basel), which were

\footnotetext{
${ }^{+}$Corresponding author. Fax: +55-21- 280.8193. E-mail: mgzalis@ibccf.biof.ufrj.br Received 22 September 1999

Accepted 20 March 2000
}

the most commonly used antimalarials in Brazil. In vitro and in vivo drug response studies from the early 1980s documented 16-63\% PS failure rates from various regions of the Amazon (Neifer \& Kremsner 1991). After one decade with continued wide availability and use of the drug, $92 \%$ of the samples collected from the State of Acre in 1987 were found to be PS resistant. Proguanil was never introduced in Brazil and no current information is available on the in vitro efficacy against Brazilian isolates of cycloguanil, the active metabolite of proguanil (Kremsner et al. 1989, Neifer \& Kremsner 1991).

Genetic analysis by polymerase chain reaction (PCR) has demonstrated the role of mutations in dihydrofolate reductase-thymidylate synthase (DHFR-TS) and dihydropteroate synthase (DHPS) genes that seem to be linked to in vitro resistance to the following drugs: pyrimethamine, cycloguanil and sulfadoxine (Cowman et al. 1988, Peterson et al. 1988, Foote et al. 1990) . 
In the case of pyrimethamine and cycloguanil, resistance is conferred by point mutations in the parasite gene encoding DHFR, leading to amino acid changes in the active site pocket of the enzyme. A Ser at position 108 is linked to sensitivity to both pyrimethamine and cycloguanil, a mutation to Asn at position 108 confers resistance to pyrimethamine but only a moderate loss of response to cycloguanil, and a Thr at position 108 (paired with an Ala to Val change at position 16) is associated with resistance to cycloguanil with only a slight loss of response to pyrimethamine. An Asn to Ile change at position 51 and a Cys to Arg change at position 59 appear to modulate higher levels of pyrimethamine resistance when they occur with the Asn-108 mutation, and an Ile to Leu mutation at position 164 in combination with the Asn-108 plus Arg-59 and/or Ile-51 mutations has been found in $P$. falciparum lines that are highly resistant to both drugs (Cowman et al. 1988, Peterson et al. 1990, Foote \& Cowman 1994). Recently, two new DHFR mutations were discovered in an area of widespread PS resistance in Bolivian samples: Cys $\rightarrow$ Arg-50 and a five amino acid repeat insertion between codons 30 and 31, termed the Bolivia repeat (Plowe et al. 1997). While both are associated with in vivo PS resistance, only the Arg-50 mutation has been shown to cause pyrimethamine resistance in transfection studies in yeast (Cortese \& Plowe 1998).

Mutations at codons 436, 437, 540, 581 and 613 of the DHPS gene have been shown to cause resistance to sulfones and sulfonamides in $P$. falciparum (Wang et al. 1997b, Triglia et al. 1997). Mutations associated with resistance are Ala-436, Gly-437, Glu-540, Gly-581, and Phe-436 combined with $\mathrm{Thr} / \mathrm{Ser}-613$. The mutation Gly-437 is highly prevalent in areas of PS resistance, suggesting that this may be the first mutation in response to drug pressure (Wang et al. 1997b).

The present paper describes the use of nested mutation-specific PCR (Plowe et al. 1995, 1997), and restriction digestion methods to measure the prevalence of DHFR mutations at amino acids positions 50, 51, 59, 108 and 164 and DHPS mutations 436, 437, 540, 581 and 613 in P. falciparum isolates from two different gold-mining areas of the State of Mato Grosso, Peixoto de Azevedo and Apiacás, and Porto Velho, capital city of Rondônia.

\section{MATERIALS AND METHODS}

Study sites - At present, clinical failures of chloroquine are reaching $100 \%$ in many areas of Bra$\mathrm{zil}$, and the drug is no longer recommended for treatment of uncomplicated $P$. falciparum malaria (Andrade et al. 1992). With the advent of chloroquine resistance, other antimalarials were intro- duced, most commonly PS. Resistance to this drug emerged rapidly and different studies have demonstrated the widespread prevalence of the DHFR Asn-108 mutation which confers moderate resistance to pyrimethamine (Alecrim et al. 1982a, b, c, Peterson et al. 1991). As a result of evidence of reduced efficacy of chloroquine and PS, the standard treatment in Brazil for uncomplicated $P$. falciparum malaria has become quinine-tetracycline. Samples were collected from 1996 to 1998 in three malaria endemic areas in Brazil. Two places of the study are the gold-mining areas, Peixoto de Azevedo and Apiacás, State of Mato Grosso, which are localized in the southern Brazilian Amazon Forest. These two localities had the highest malaria transmission rates in Brazil, $~ 300$ cases/week in 1996. The samples from Porto Velho, capital of the State of Rondônia, were collected in 1998.

Sample collection and control parasites - At the three sites of this study we performed the same sample collection procedure. Five milliliters of blood were collected from adult men (ages 18-65) with uncomplicated smear-confirmed falciparum malaria (1,000 - 100,000 ring forms/ $\mu$ l of blood) at the Fundação Nacional de Saúde (National Health Foundation) posts by venipuncture using vacutainers with EDTA (Beckton and Dickinson, $\mathrm{NJ})$.

The samples were centrifuged and the pellet containing packed blood cells was mixed with equal volume of cryopreservation solution $(\mathrm{NaCl}$ $0.9 \%$, sorbitol $4.2 \%$, glycerol $28 \%$ ) frozen and transported in liquid nitrogen containers to Rio de Janeiro. Nine samples from Peixoto de Azevedo and Apiacás were successfully grown in vitro by the modified method of Trager and Jensen (1997) and used for the in vitro drug test analysis. The W2 and HB3, PS resistant clones and D6, PS sensitive clone were used as controls (de Pecoulas et al. 1996).

DNA extraction - One $\mathrm{ml}$ of blood was centrifuged and suspended in NET Buffer $(150 \mathrm{mM}$ $\mathrm{NaCl}, 10 \mathrm{mM}$ EDTA, 50mM Tris, $\mathrm{pH} 7.5$ ) and treated with $1 \%$ sarcosyl and proteinase $\mathrm{K}(20 \mathrm{mg} /$ $\mathrm{ml}, 2 \mathrm{~h}$ at $\left.50^{\circ} \mathrm{C}\right)$. DNA was then extracted using phenol, phenol/chloroform and chloroform, precipitated with sodium acetate $(0.3 \mathrm{M})$ and ethanol, and resuspended in distilled water.

Nested mutation-specific PCR - PCR was done as previously described for analysis of the DHFR mutation sites (Plowe et al. 1995, 1997) (Fig. 1). The DHFR domain obtained from the first PCR amplification round, which used the oligonucleotide primer pair AMP1/AMP2, was used as a template in mutation-specific second amplification to assess all the DHFR mutation sites. 


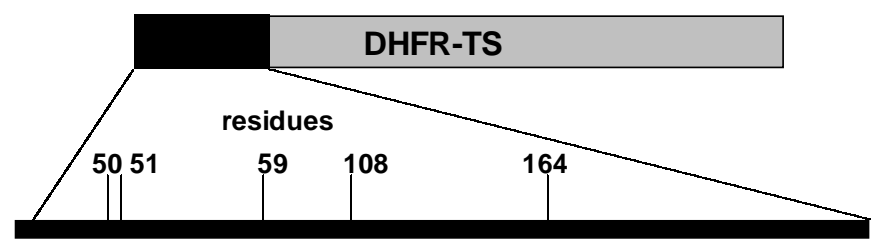

First round

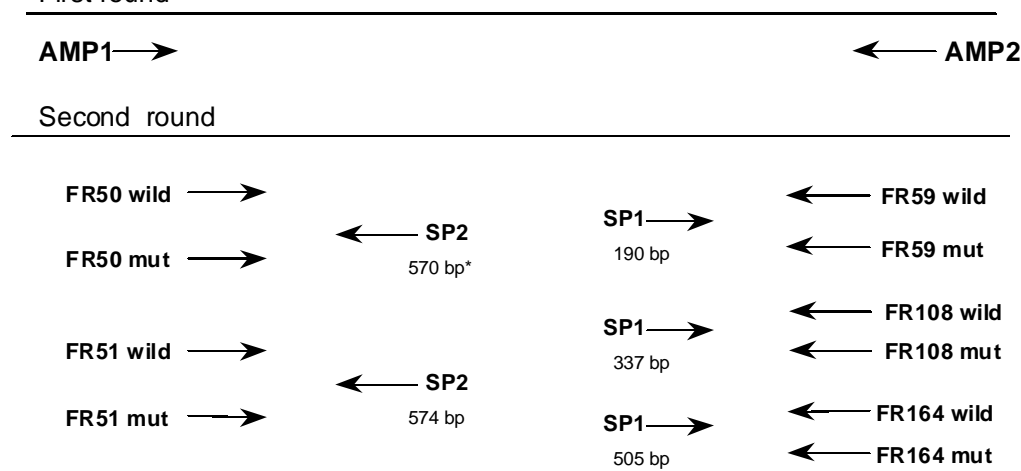

Fig. 1: strategy of the nested polymerase chain reaction (PCR) for dihydrofolate reductase-thymidylate synthase mutations analysis. * PCR fragment size expected after the second round.

For codon 50, mutation-specific sense primers FR50w, which contains the codon for the wild type Cys and FR50m, which contains the mutant codon for Arg, were paired with the antisense primer SP2 for a PCR product of $570 \mathrm{bp}$. The mutation-specific sense primers FR51w, which specifically amplifies sequence containing the wild type AAT (Asn) codon, and FR51m, which is specific for the mutant codon ATT (Ile), were paired with the common antisense primer SP2, for a final product of 574 bp. The codon 59 was analyzed with the antisense primers FR59w, specific for the wild type Cys and FR59m specific for mutant codon Arg, were paired with the common sense primer SP1 with a product size of $190 \mathrm{bp}$. Detection of the DHFR Bolivia repeat was done by size determination of the amplified PCR product corresponding to the DHFR domain 5' to codon 59. For the analysis of the DHFR codon 108 the common sense SP1 were paired DIA-3 for the wild-type codon Ser, DIA-12 for the mutant codon Asn and DIA-9 for the mutant codon Thr. The final PCR product was $337 \mathrm{bp}$. For codon 164 the SP1 primer was paired with the antisense primers FR164w specific for the wild-type codon Ile and FR164m and gave a final product of $505 \mathrm{bp}$.

Detection for the known DHPS mutations at the codons 436, 437, 540, 581 and 613 was done as described (Wang et al. 1997a, b) (Fig. 2). Five microliters of the genomic $P$. falciparum DNA was amplified in a $50 \mathrm{ml}$ reaction using mutation- specific PCR and restriction digestion methods (Wang et al. 1995, Plowe et al. 1997).

Determination of the antimalarial activity of antifolates - The drugs used in this study were obtained from the Division of Experimental Therapeutics, The Walter Reed Army Institute of Research, Washington, D.C. Methods for the quantitative assessment of anti-malarial drugs on a semiautomated microdilution technique were described previously (Milhous et al. 1985). Determinations of the $\mathrm{IC}_{50}$ (Inhibitory Concentration at $50 \%$ ) were made for sulfadoxine, pyrimethamine, cycloguanil and proguanil in a folate-free and PABA-free RPMI-1640 medium (GIBCO BRL, Grand Island, NY) with $32 \mathrm{mM} \mathrm{NaHCO}$ (GIBCO), $25 \mathrm{mM}$ HEPES (GIBCO), dialyzed human plasma and $\mathrm{A}^{+}$erythrocytes.

Parasites were set up on the above deficient medium at initial $0.5 \%$ parasitemia, $2.5 \%$ haematocrit, $225 \mu \mathrm{l}$ final volume, in 96-well microtiter plates. For each drug, two columns of seven wells was reserved. In the first seven rows (rows A-G) the drugs were added in a descending order of $3 \mathrm{x}$ concentration. The drug concentration range used to establish $\mathrm{IC}_{50}$ values was $0-12 \mu \mathrm{g} /$ $\mathrm{ml}$ for all the drugs. In the 8th row, the first six wells had only parasites with any drug (maximum radioactive uptake) and the last six wells had uninfected erythrocytes as controls for background incorporation of radioactive label. The microtiter plate was placed in a box, gassed with $5 \% \mathrm{CO}_{2}$, 

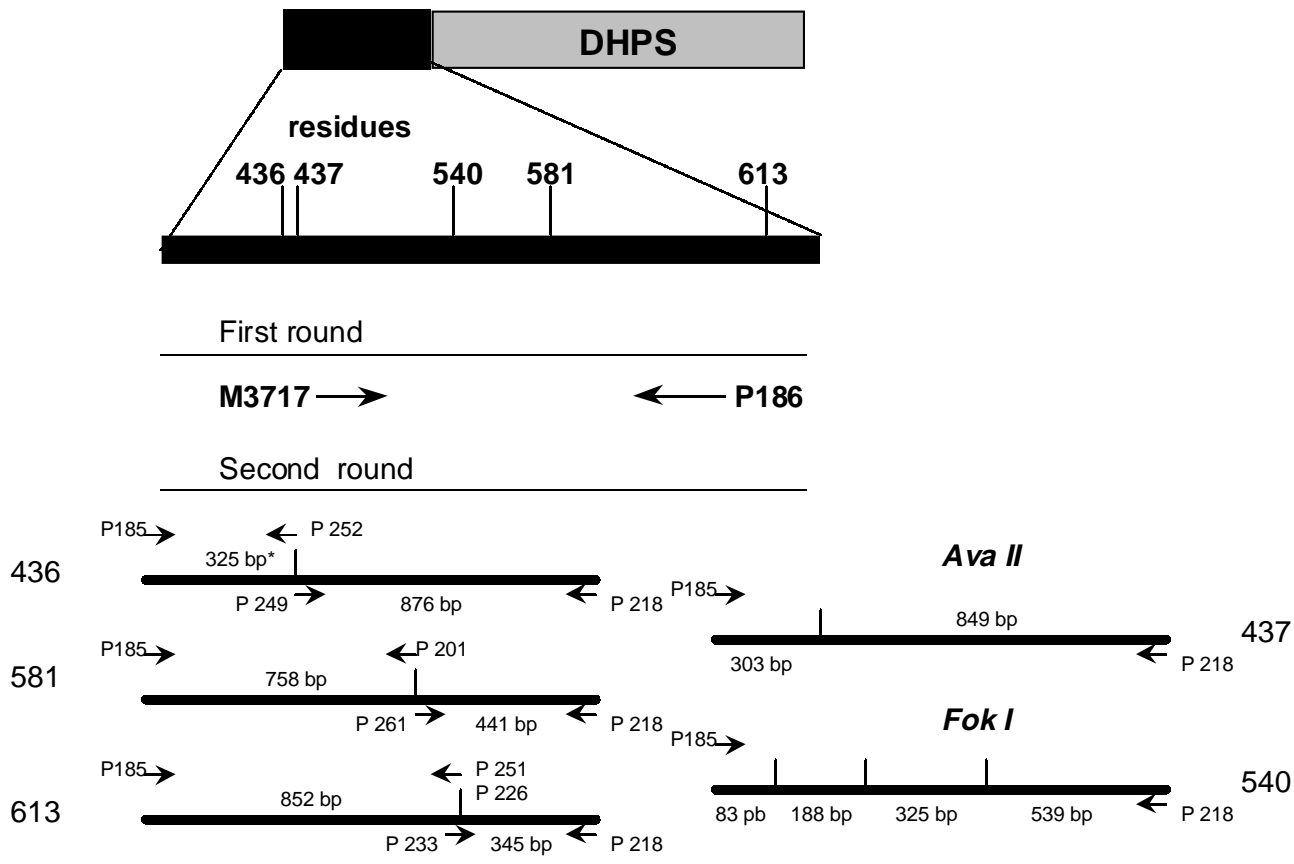

Fig. 2: strategy of the nested polymerase chain reaction (PCR) for dihydropteroate synthase mutation analysis. For residues analysis of the 437 and 540 amino acids, restriction digestion was performed after the second amplification. * PCR fragment size expected after the second round.

$5 \% \mathrm{O}_{2}, 90 \% \mathrm{~N}_{2}$, and sealed. After $48 \mathrm{~h}$ incubation with the drugs at $37^{\circ} \mathrm{C}, 0.5 \mu \mathrm{Ci}\left[{ }^{3} \mathrm{H}\right]$ hypoxanthine in $25 \mu$ of test medium was added to each well to monitor growth and samples were processed after a further $16 \mathrm{~h}$. After harvesting the well contents, the filters were counted in a scintillation counter (Wallac) and the incorporation data were analyzed by non-linear regression software -NFIT (University of Texas, Medical Branch, Galveston) in order to generate $\mathrm{IC}_{50} . \mathrm{IC}_{50}$ values were defined as the concentration of antifolate drugs at which parasite growth was reduced to half that of the untreated controls, as measured by tritium incorporation.

\section{RESULTS}

DHFR genotypes - Seventeen samples from Peixoto de Azevedo, ten from Apiacás and fifteen from Porto Velho were analyzed by PCR and restriction digestion. All fragments size corresponded to those described previously (Plowe et al. 1995, 1997, Wang et al. 1997b). DHFR genotypes are shown in Table I and DHPS genotypes in Table II. All samples collected in Peixoto showed only one genotype, with the following DHFR mutations: Arg50, Ile-51, Cys-59, Asn-108 and Ile-164. Samples from Apiacás, however, showed two distinct genotypes: six out of ten showed the same allelic variation observed in Peixoto, but four out of ten were found to have the genotype Cys-50, Ile-51, Cys-59,
Asn-108 and Leu-164 associated with high levels of resistance to both pyrimethamine and cycloguanil. These four samples were also found to contain the Bolivia repeat (BR) (Plowe et al. 1997).

The Thr-108 DHFR mutation, which confers resistance to cycloguanil, was not found in Peixoto or in Apiacás, but was detected in eleven Porto Velho samples as a mixed population with the mutation Asn-108. The samples collected in Porto Velho showed considerably more allelic variation and fewer mutations than those from Peixoto and Apiacás. Two samples from Porto Velho were mutated only at codon 108 with both Thr and Asn mutations in the same samples. Five Porto Velho samples had wild type Cys at codon 50 and seven had wild type Asn at codon 51, whereas all Peixoto and Apiacás samples were mutated at these codons.

DHPS genotypes - All samples from Peixoto and Apiacás had the wild-type Ser-436 and Ala613 but sulfadoxine resistance-associated mutations Gly-437, Glu-540 and Gly-581 (Table II). Seven out of fifteen samples analyzed in Porto Velho had the Ala-436 DHPS mutation.

In vitro drug test - Four samples from Peixoto and five from Apiacás were cultured and after two weeks in vitro tested against pyrimethamine, cycloguanil, proguanil and sulfadoxine (Table III). All the samples were found to be resistant to Pyr 
TABLE I

Frequency of dihydrofolate reductase genotypes of samples isolated from three different regions of the Brazilian Amazon

\begin{tabular}{|c|c|c|c|c|c|c|c|}
\hline \multirow[b]{2}{*}{ Site } & \multirow[b]{2}{*}{$\mathrm{BR}$} & \multicolumn{5}{|c|}{ Amino acid position } & \multirow[b]{2}{*}{ Frequency $\%(\mathrm{n})$} \\
\hline & & 50 & 51 & 59 & 108 & 164 & \\
\hline $\begin{array}{l}\text { Peixoto de Azevedo } \\
\mathrm{n}=17\end{array}$ & & Arg & Ile & Cys & Asn & Ile & $100(17)$ \\
\hline $\begin{array}{l}\text { Apiacás } \\
\mathrm{n}=10\end{array}$ & $\overline{\mathbf{B R}}$ & $\begin{array}{l}\text { Arg } \\
\text { Arg }\end{array}$ & $\begin{array}{l}\text { Ile } \\
\text { Ile }\end{array}$ & $\begin{array}{l}\text { Cys } \\
\text { Cys }\end{array}$ & $\begin{array}{l}\text { Asn } \\
\text { Asn }\end{array}$ & $\begin{array}{l}\text { Ile } \\
\text { Leu }\end{array}$ & $\begin{array}{l}60(6) \\
40(4)\end{array}$ \\
\hline $\begin{array}{l}\text { Porto Velho } \\
n=15\end{array}$ & $\begin{array}{l}- \\
- \\
- \\
-\end{array}$ & $\begin{array}{l}\text { Arg } \\
\text { Cys } \\
\text { Arg } \\
\text { Cys } \\
\text { Cys } \\
\text { Arg }\end{array}$ & $\begin{array}{l}\text { Ile } \\
\text { Ile } \\
\text { Asn } \\
\text { Asn } \\
\text { Asn } \\
\text { Ile }\end{array}$ & $\begin{array}{l}\text { Cys } \\
\text { Cys } \\
\text { Cys } \\
\text { Cys } \\
\text { Cys } \\
\text { Cys }\end{array}$ & $\begin{array}{c}\text { Asn+ Thr } \\
\text { Asn } \\
\text { Asn+ Thr } \\
\text { Asn } \\
\text { Asn+ Thr } \\
\text { Asn }\end{array}$ & $\begin{array}{l}\text { Ile } \\
\text { Ile } \\
\text { Ile } \\
\text { Ile } \\
\text { Ile } \\
\text { Ile }\end{array}$ & $\begin{array}{c}33.3(5) \\
13.3(2) \\
26.7(4) \\
6.7(1) \\
13.3(2) \\
6.7(1)\end{array}$ \\
\hline
\end{tabular}

BR: Bolivia repeat. Mutations are indicated in bold.

TABLE II

Frequency of dihydropteroate synthase genotypes of samples isolated from three different regions of the Brazilian Amazon

\begin{tabular}{lcccccc}
\hline & \multicolumn{9}{c}{ Amino acid position } & \\
\cline { 2 - 6 } Site & 436 & 437 & 540 & 581 & 613 & Frequency \% (n) \\
\cline { 1 - 6 } $\begin{array}{l}\text { Peixoto de Azevedo } \\
\mathrm{n}=17\end{array}$ & Ser & Gly & Glu & Gly & Ala & $100(17)$ \\
$\begin{array}{l}\text { Apiacás } \\
\mathrm{n}=10\end{array}$ & Ser & Gly & Glu & Gly & Ala & $100(10)$ \\
$\begin{array}{l}\text { Porto Velho } \\
\mathrm{n}=15\end{array}$ & Ser & Gly & Glu & Gly & Ala & $53.3(8)$ \\
\hline
\end{tabular}

Mutations are indicated in bold.

and sulfadoxine and showed to have reduced susceptibility to cycloguanil and proguanil when compared with the susceptible strain D6 (Sierra Leone). The inhibitory concentrations $\left(\mathrm{IC}_{50}\right)$ values to pyrimethamine range from 48 to $98 \mathrm{ng} / \mathrm{ml}$ in the Peixoto and 50.8 to $87.4 \mathrm{ng} / \mathrm{ml}$ in Apiacás. For cycloguanil, the IC50 levels varied from 2.9 to 4.75 and 1.42 to $2.42 \mathrm{ng} / \mathrm{ml}$ in Peixoto and Apiacás, respectively. In Apiacás and Peixoto the $\mathrm{IC}_{50}$ for proguanil range from 331 to $1,125 \mathrm{ng} / \mathrm{ml}$ and 320 to $1,657 \mathrm{ng} / \mathrm{ml}$, respectively.

Although proguanil is not the active metabolite, this drug showed an antimalarial activity in a nanomolar range, suggesting an independent mechanism of parasite inhibition by the proguanil. For sulfadoxine, the levels varied from 1,357 to $6,987 \mathrm{ng} / \mathrm{ml}$ in the Peixoto samples and from 1,043 to $1,686 \mathrm{ng} / \mathrm{ml}$ in Apiacás. In comparison to the sensitive strain D6, the Brazilian parasites were in average 700 fold more resistant to pyrimethamine, ten fold to cycloguanil, four fold to proguanil and eight fold more resistant to sulfadoxine.

\section{DISCUSSION}

In 1972, resistance to PS was first reported in Brazil shortly thereafter in Colombia. In Brazil, in vitro and in vivo drug studies from the early 80 s documented $16-63 \%$ PS failure rates in various regions of the Amazon (Alecrim et al. 1982a, b, c). After one decade of wide availability and use of the drug, $92 \%$ of samples collected from the State of Acre in 1987 were found to be PS resistant (Neifer et al. 1991). Today this drug combination is not recommended for use in any region of Brazil.

This study describes antifolate resistance mutations in three different communities of the Brazilian Amazon. In the two gold-mining areas Peixoto and Apiacás, only two distinct genotypes associated with pyrimethamine resistance were found, one with the DHFR mutations Ile-51 and Asn- 108 and the second DHFR mutations at Cys59, Asn-108 and Leu-164 associated with high level resistance to pyrimethamine and cycloguanil. The samples from Porto Velho were less highly 


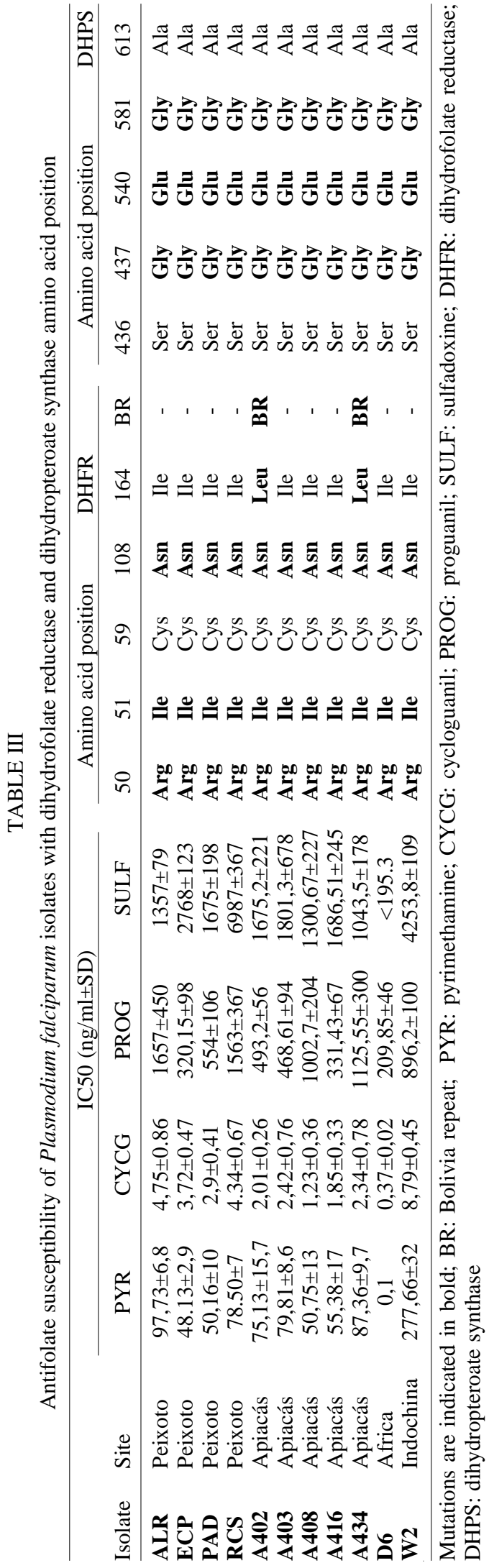

mutated with more allelic variation than those from Peixoto and Apiacás. In Porto Velho, samples originated from several different river communities. In this region, there is intense internal migration from different parts of the Amazon as well as in- and out-migration from Bolivia and Peru. The higher degree of host mobility may explain the increased allelic variation in this area.

Interestingly, we found the relatively rare $\mathrm{Thr}-$ 108 DHFR mutation in four samples from Porto Velho. These samples were analyzed three times to confirm the presence of this mutation. DNA sequencing studies are planned to verify these results and to rule out the presence of novel DHFR mutations.

In this study were found $40 \%$ of the analyzed samples from Apiacás the mutation Leu in position 164 of the falciparum DHFR, which is associated with in vivo and in vitro cycloguanil resistance. Although proguanil has never been reported as being used for the treatment of malaria in Brazil, the appearance of this mutation could be explained by the introduction in Brazil of a parasite population containing this mutation or by the previous pyrimethamine selection when the drug was used.

In addition, the Bolivia repeat previously reported by Plowe et al. (1997) was always in combination with this point mutation. This repeat which is localized in 5'domain of the DHFR, was previously found in all Bolivian samples with the mutant Leu-164. Antifolate resistance due to DHFR mutations expressed in yeast was not increased with the Bolivia repeat in addition to the Leu-164. Despite the Bolivian policy to stop the use of pyrimethamine-sulfadoxine, approximately 500,000 tables were consumed in 1995 (Kublin et al. 1998) in the country. With high in migration from Bolivia to Brazil, the Bolivia repeat in combination with the Arg-50 and Leu-164 was probably recently introduced by Bolivian migrants specifically in the Apiacás region and not in Peixoto. Apiacás is localized $200 \mathrm{~km}$ from Peixoto and has the same gold-miners migration pattern. This is the first evidence of these mutations in Brazil and we could trace this parasites studying other samples from different malaria endemic areas of Brazil.

The most common DHPS genotype at the study sites contained the mutations Gly-437, Glu-540 and Gly-581, which has also been observed in areas of high PS resistance in Peru and Bolivia (Kublin et al. 1998). The DHPS Ala-436, which was not found in Peru and Bolivia, was present only in Porto Velho, where overall mutation rates were lower. This is consistent with the observation that Ala436, while associated with sulfa resistance in vitro, is inversely associated with in vivo PS resistance 
(Kublin et al. 1998).The Gly-437, which is present in sulfa-resistant strains from different parts of the world, appears to be the first selected mutation in DHPS enzyme from resistant parasites.

The indiscriminate and unsupervised use of sulfonamides for bacterial infections in areas where malaria is prevalent is common in Brazil (Cor Jésus Fontes, pers. commun.) and despite the Brazilian policy to control the general use of sulfa drugs, they are widely available commercially in Brazil. Given that the role of DHPS mutations in clinical failure of PS remains controversial (Kublin et al. 1998), the use of sulfa drugs for bacterial infections must be considered as a possible explanation of the high prevalence of DHPS mutations at the study sites.

The DHFR and DHPS mutation patterns found in this study suggest that reintroduction of PS to these areas of Brazil cannot be recommended, based on a high prevalence of in vivo resistance in Peruvian samples containing similar mutation patterns. Our findings also have implications for the choice of other new antimalarial combinations for use in Brazil. For example, combinations of shorter-acting antifolates such as chlorproguanil/ dapsone (Kublin et al. 1998) or proguanil/ sulfamethoxazole have been considered as a strategy for deterring the emergence of antifolate-resistant parasites. Unfortunately, the presence of mutations such as DHFR Leu-164 that have been associated with resistance to these DHFR inhibitors may predict that these drugs would not perform well in the areas surveyed in this study. Additional studies of the relationship between DHFR and DHPS genotypes and therapeutic outcomes for these antifolate combinations are needed to validate the use of molecular assays for antifolate resistance as a basis for setting antimalarial drug treatment policy in different settings.

\section{REFERENCES}

Alecrim MG, Alecrim WD, de Albuquerque BC, Dourado HV, Wanssa MD 1982a. In vivo resistance of Plasmodium falciparum to the combination of sulfamethoxazole and trimethoprim in the Brazilian Amazonas. Rev Inst Med Trop São Paulo 24: 4851.

Alecrim MG, Alecrim WD, de Albuquerque BC, Dourado HV, Wanssa MD 1982b. Resistance of Plasmodium falciparum in the Brazilian Amazon to the combination of sulfadoxine and pyrimethamine. Rev Inst Med Trop São Paulo 24: 44-47.

Alecrim WD, Dourado H, Alecrim MG, Passos LF, Wanssa $\mathrm{E}$, Albuquerque B 1982c. In vitro resistance of Plasmodium falciparum to the combination of sulfadoxine and pyrimethamine, at RIII level, in Amazonas, Brazil. Rev Inst Med Trop São Paulo 24: $52-53$.
Andrade JG, Andrade ALS, Araujo ESO, Oliveira RM, Silva AS, Martelli CMT, Zucker F 1992. A randomized clinical trial with high dose of chloroquine for treatment of Plasmodium falciparum malaria in Brazil. Rev Inst Med Trop São Paulo 34: 467-473.

Cortese JF, Plowe CV 1998. Antifolate resistance due to new and known Plasmodium falciparum dihydrofolate reductase mutations expressed in yeast. Mol Biochem Parasitol 94: 205-214.

Cowman AF, Morry MJ, Biggs BA, Cross GA, Foote SJ 1988. Amino acid changes linked to pyrimethamine resistance in the dihydrofolate reductase-thymidylate synthase gene of Plasmodium falciparum. Proc Natl Acad Sci USA 85: 9109-9113.

de Pecoulas PE, Basco LK, Le Bras J, Mazabraud A 1996. Association between antifolates resistance in vitro and DHFR gene point mutation in Plasmodium falciparum isolates. Trans R Soc Trop Med Hyg 90: 181-182.

Foote SJ, Cowman AF 1994. The mode of action and the mechanism of resistance to antimalarial drugs. Acta Trop 56: 157-171.

Foote SJ, Galatis D, Cowman AF 1990. Amino acids in the dihydrofolate reductase-thymidylate synthase gene of Plasmodium falciparum involved in cycloguanil resistance differ from those involved in pyrimethamine resistance. Proc Natl Acad Sci USA 87: 3014-3017.

Kremsner PG, Zotter GM, Feldmeier H, Graninger W, Kollaritsch M, Wiedermann G, Rocha RM, Wernsdorfer WH 1989. In vitro drug sensitivity of Plasmodium falciparum in Acre, Brazil. Bull World Health Org 67: 289-293.

Kublin JG, Witzig RS, Shankar AH, Zurita JQ, Gilman RH, Guarda JA, Cortese JF, Plowe CV 1998. Molecular assays for surveillance of antifolate-resistant malaria. Lancet 351: 1629-1630.

Marques AC 1993. Epidemiologic data on malaria in the Amazon region, by municipality, in 1992. Rev Soc Bras Med Trop 26: 43-59.

Marques AC 1995. Epidemiological data on malaria for all of Brazil in 1993. Rev Soc Bras Med Trop 28: 141-155.

Milhous WK, Weatherly NF, Bowdre JH, Desjardins RE 1985. In vitro activities and mechanisms of resistance to antifolates. Antimicrob Agents Chemother 27: 525-530.

Neifer S, Kremsner PG 1991. Drug susceptibility of Plasmodium falciparum in the western Amazon region, State of Acre, Brazil. Rev Inst Med Trop São Paulo 33: 205-211.

Peterson DS, Walliker D, Wellems TE 1988. Evidence that a point mutation in dihydrofolate reductasethymidylate synthase confers resistance to pyrimethamine in falciparum malaria. Proc Natl Acad Sci USA 85: 9114-99118.

Peterson DS, Milhous WK, Wellems TE 1990. Molecular basis of differential resistance to cycloguanil and pyrimethamine in Plasmodium falciparum malaria. Proc Natl Acad Sci USA 87: 3018-3022.

Peterson DS, di Santi SM, Povoa M, Calvosa VS, Do Rosario VE, Wellems TE 1991. Prevalence of the 
dihydrofolate reductase Asn-108 mutation as the basis for pyrimethamine-resistant falciparum malaria in the Brazilian Amazon. Am J Trop Med Hyg 45: 492-497.

Plowe CV, Cortese JF, Djimde A, Nwanyanwu OC, Watkins WM, Winstanley PA, Estrada-Franco JG, Mollinedo RE, Avila JC, Cespedes JL, Carter D, Doumbo OK 1997. Mutations in Plasmodium falciparum dihydrofolate reductase and dihydropteroate synthase and epidemiologic patterns of pyrimethamine-sulfadoxine use and resistance. $J$ Infect Dis 176: 1590-1596.

Plowe CV, Djimde A, Bouare M, Doumbo O, Wellems TE 1995. Pyrimethamine and proguanil resistanceconferring mutations in Plasmodium falciparum dihydrofolate reductase: polymerase chain reaction methods for surveillance in Africa. Am J Trop Med Hyg 52: 565-568.

Trager W, Jensen JB 1997. Continuous culture of Plasmodium falciparum: its impact on malaria research. Int J Parasitol 27: 989-1006.

Triglia T, Menting JG, Wilson C, Cowman AF 1997. Mutations in dihydropteroate synthase are responsible for sulfone and sulfonamide resistance in Plasmodium falciparum. Proc Natl Acad Sci USA 94:
13944-13949.

Wang P, Brooks DR, Sims PF, Hyde JE 1995. A mutation-specific PCR system to detect sequence variation in the dihydropteroate synthetase gene of Plasmodium falciparum. Mol Biochem Parasitol 71: 115125.

Wang P, Lee CS, Bayoumi R, Djimde A, Doumbo O, Swedberg G, Dao LD, Mshinda H, Tanner M, Watkins WM, Sims PF, Hyde JE 1997a. Resistance to antifolates in Plasmodium falciparum monitored by sequence analysis of dihydropteroate synthetase and dihydrofolate reductase alleles in a large number of field samples of diverse origins. Mol Biochem Parasitol 89: 161-177.

Wang P, Read M, Sims PF, Hyde JE 1997b. Sulfadoxine resistance in the human malaria parasite Plasmodium falciparum is determined by mutations in dihydropteroate synthetase and an additional factor associated with folate utilization. Mol Microbiol 23: 979-986.

Zalis MG, Pang L, Silveira MS, Milhous WK, Wirth DF 1998. Characterization of Plasmodium falciparum isolated from the Amazon region of Brazil: evidence for quinine resistance. Am J Trop Med Hyg 58: 630-637. 